\title{
Improving the Resilience of Banking System in Small Open Economy: Is Macroprudential Policy Efficient?
}

\author{
Petra Popek Biskupec ${ }^{1, *}$, Suzana Herman ${ }^{2}$ \\ ${ }^{1}$ University of Appiled Sciences, Zapresic, Department of Finance, Vladimira Novaka, 23, 10290 \\ Zapresic, Croatia \\ ${ }^{2}$ University of Appiled Sciences, Zapresic, Department of Economy, Vladimira Novaka, 23, 10290 \\ Zapresic, Croatia
}

\begin{abstract}
Research background: Although macroprudential instruments increase financial stability, it is necessary to test how they affect the overall economic recovery after a global financial crisis. In the post-crisis period, the real sector needed a strong injection of capital in order to be able to start recovery and to encourage economic growth. At the same time, most of the countries introduced strict regulatory measures that strengthen bank capital and the liquidity base. From the standpoint of the financial sector stability, these measures contributed to the overall financial stability, but at the same time, these measures hold up the bank credit activity.

Purpose of the article: This paper analyses the impact of macroprudential instruments on the bank credit activity toward the non-financial sector. The analysis is made by using the Granger Causality Test and the ARLDS Bounds Test.

Methods: The research was conducted for the period of $2000-2019$, based on the data of the Croatian National Bank and the Croatian Bureau of Statistics using logarithmic quarterly data. The analysis is made by using the Granger Causality Test and the ARLDS Bounds Test.

Findings \& Value added: The results confirm the thesis that additional macroprudential measures decrease the bank credit activity toward the real sector, which slows down the real sector recovery and extends the downturn in the business cycle. On the other hand, the macroprudential measures increase the financial stability of the whole economy, which is positive for future investments and recovery of the real sector.
\end{abstract}

Keywords: macroprudential policy; banking system; open economy

JEL Classification: $E 5$; E52; E58

* Corresponding author : pbiskupec@bak.hr 


\section{Introduction}

As the response to the overall financial crisis that started in 2008, every country has started to strengthen its framework in order to build stronger financial system. Due to the global integration of financial institutions, it is necessary to create efficient supervision and regulation of the financial and banking system could be more resistant to the future shocks and crises. New supervisory framework, known as macroprudential regulation, besides financial institutions includes their global integrations and interconnection, as the interconnectedness of financial institutions and markets had huge impact on materialization of systemic risk in the financial system. [10,31] Macroprudential policy mitigates total risk exposures of the financial sector and has countercyclical character in order to achieve and maintain macroeconomic financial stability. Financial stability can be defined as resilience of the financial system to internal and external shocks. The European central bank defines financial stability ,as a condition in which the financial system - which comprises financial intermediaries, markets and market infrastructures - is capable of withstanding shocks and the unravelling of financial imbalances “ [15]. After financial crisis in 2008 had escalated, everybody realized that full financial liberalization had many disadvantages. Removing capital barriers and liberalization of capital flows contributed to accumulation of systemic risk, which later contributed to financial crisis escalation. The new approach, known as macro prudential policy, became very popular and most welcomed. Macro prudential policy places focus on capital controls which brings more regulations in supervision of the financial sector. As the European Union is a bank-centric system, the supervisors have to focus on bank supervision and macro prudential regulation of banking system. Macroprudential instruments act countercyclical to amplification of systemic risk and diminish the possibility of disruption in financial services. Due to that, macroprudential policy creates a more resilient financial system [23]. In coordination with monetary policy, macroprudential instruments help to reduce risk of entering into a financial crisis and speeds up exit from the crisis [40]. In order to be effective in diminishing systemic risk, macroprudential policy should not rely on rules but must be based on continuous assessment of evolving risks. Macro prudential policy use key indicators and consider all relevant information such as changes in financial markets, insurance sector, and among pension funds and asset managers, to predict future trends and movement of the financial sector as a whole [21]. The most popular macroprudential tool is countercyclical capital buffer, which is designed to protect banks from procyclical behaviour during the boom in financial cycle and building-up systemic vulnerabilities [4]. The analysis of macro prudential regulation in the European Union from 1995 until 2014 suggest that a share of instruments available in the present macro prudential toolbox, such as capital buffers, regulatory lending standards or liquidity caps, may have had an impact on credit to nonfinancial private sector in the EU. [7] Although, macroprudential framework is very popular among supervisors, many started to question its effectiveness. The higher costs of restrictive macro prudential policy are named as its biggest disadvantage. The strategy „leaning against the wind "contributes to decrease real debt growth and probability of materialization of financial risks, but on the other hand, it increases unemployment and decrease inflation, which finally makes the costs of a possible crisis higher [34]. In this paper, we analyse the effectiveness of macroprudential tools. We test the impact of macroprudential instruments (countercyclical capital buffer, reserve requirement and minimum required foreign currency claims) on bank credit activity toward the non-financial sector. The analysis is made by using Granger Causality Test and ARLS Bounds Test. The results confirm the thesis that additional macroprudential measures decrease the banks' credit activity toward the real sector, which slows down the real sector recovery and extends the downturn in the business cycle. On the other hand, banks in the countries with 
stronger countercyclical framework have better financial strength ratings [11]. Due to that, macroprudential measures increase the financial stability of the whole economy, which is positive for future investments and recovery of real sector.

\section{Research review}

Since global financial crisis 2008, the regulators steam even more from asymmetric information and negative externalities and materialisation of several of risks that could arise from increasing advantage, expanding balance sheets and relying on short-term liquidity. [24] The quality of collateral could be mispresented, what contributes to the increasing of systemic risk. Due to the earning extra profit, banks could fake the quality of mortgage debt and debtors could fake the quality of real estate intended as a collateral [41]. As the theory and practice confirmed, the macroeconomic and financial stability are interconnected, and the policy makers started to combine monetary and prudential policies. The central banks are using prudential instruments (countercyclical capital buffer) to prevent excessively risktaking by banks [9]. Also, the unconventional monetary policy reduces the market tail risks and interest rate risks [20]. In small open economies that depend on international capital flows, monetary instruments have very little impact on total financial stability. The borrowers in many emerging economies extensively were taking loans in foreign currency or in domestic currency with a foreign currency clause. The huge pressure on domestic currency, because of oscillations in inflows and outflows of foreign capital, force monetary authorities to use monetary instruments for preserving the stability of the foreign exchange rate and the central bank is using the macroprudential instruments to address currency mismatches and the impact of fluctuation in capital flows [39]. In this situation, central bank is focused on maintaining the stability of exchange rate in order to keep price stability, by using foreign exchange intervention, particularly in turbulent times [16], and can no longer actively act in supporting economic growth. In addition, the financial system that is bank-centric impose the need for strong banking supervision, because the main capital flows refer to banking system. All these facts restrict the activity of central bank in using monetary policy instruments and this is the reason why central banks of small open countries introduced non-standard monetary policy measures and macroprudential instruments much earlier than financial crises started. Levine and Lima [25] proved that there is a welfare benefit from countercyclical type of monetary policy and macroprudential regulation even in the case in which monetary and macroprudential authorities are independent and react to their own policy goal. Moder [29] estimates the response of output and prices for south-eastern European countries to non-standard monetary policy measures and finds that the ECB's non-standard monetary policy measures have had pronounced price effects on all south-eastern European countries. As the theory and practice confirmed that macroeconomic and financial stability are interconnected, the policy makers are interconnected, the policy makers started to combine monetary and prudential policies. The central banks are using prudential instruments (countercyclical capital buffer) to prevent excessively risk-taking by banks. [9]. A simple equilibrium model [28] showed that optimal central bank prudential, monetary and balance sheet policies were needed after 2008. Some studies showed that when capital controls are part of the optimal policy mix, the higher welfare could be achieved. [5] Since banks are very significant providers of credit to the economy, macroprudential measures and instruments typically applies its policy levers to the banking system [22]. Among others, macroprudential instruments refers to strengthening capital base (e.g. countercyclical requirements, and restrictions on profit distribution) and liquidity base (e.g. limits on net open currency positions of assets and liabilities, limits on maturity mismatch of assets and liabilities, reserve requirements and dynamic provisioning) in order to diminish systemic risk. In addition, the macroprudential 
instruments have counter cycle impact on banks credit activity using caps on the loan-tovalue (LTV) ratio, caps on the debt-to-income (DTI) ratio, and caps on foreign currency lending and ceilings on credit or credit growth [26]. The problem with excessive credit activity of financial institutions also arose from boom-bust cycles in real estate markets in European countries. The prices of properties and assets in general were overestimated which indicated the better position of borrowers and less risky individual credit lines from the perspective of value of real estate as a loan insurance instrument. As the credit and asset prices have common cyclical similarities [33], the huge problem occurred when the prices of real estates started to decrease rapidly and the value of the real estates was not enough to cover the amount of insured loan. At the same time, the entire economy was affected by crises and many good debtors became bad debtors. Because of this phenome, the regulators were forced to introduce more effective instruments that are countercyclical and are able to diminish the credit risk in future bank credit activity. The macroprudential measures, like countercyclical capital buffer, are able to dampen the fluctuations of the housing prices and to decrease amplitudes of boom and bust cycles for small open economies [27]. In addition, the analyses showed that unconventional monetary policies and macroprudential instruments tend to reduce credit risk and increase bank stock returns [1]. Finally, borrower-based regulatory policies are effective in reducing the increase of prices at real estate market. Macroprudential instruments that act countercyclical to real estate prices boom are debt-to-income and loan-to-value limits [19]. Schuler et al. [33] showed that the credit-to-GDP gap has good performance in predicting systemic banking crises on a horizon of up to three years. Also, in period of welfare every subject, including bank, is willing to take a higher amount of risk. To diminish risk-taking banks' behaviour, regulators ask for certain amount capital that is held as equity capital. The level of required capital in the European union is standardized by Capital Requirement Directive IV* (CRD IV) package and includes Capital Requirements Directive (2013/36/EU) and Capital Requirements Regulation (575/2013) (Directive 2013/36/EU, 2103). CRD IV implements the Basel III standards in the legislative EU and brings more macroprudential rules for banking system. The aim of CRD IV is to increase the quality and quantity of banks capital, to improve liquidity and leverage level, decrease counterparty risk, and finally reduce the systemic risk of banking sector [3]. Capital and liquidity buffers have impact to bank responses to monetary policy shocks. High bank capitalisation and high bank liquidity have positive impact on the bank's credit activity toward non-financial corporate sector [6].

Basten and Koch [4] analysed how the introduction of the countercyclical buffer has affected mortgage pricing and they found that because of increased capital requirements mortgage-specialized banks raise prices more than their competitors did. The second finding refers to shifting mortgages from less resilient banks to more resilient banks, although authors found that capital requirements did not discourage less resilient banks from risky mortgage lending. Chen and Columba (2016) find that demand-side macroprudential tools are more effective in decreasing household debt ratios than monetary policy tools. Altunbas et.al. [2] investigate the impact of macroprudential instruments on bank risk in advanced and emerging markets. The authors found that macroprudential instruments have a significant impact on bank risk, but they are more effective in tightening than in an easining regime.

On the other hand, many started to question the justification of extensive use of macroprudential instruments, especially in periods of downturns in business and credit

\footnotetext{
* Directive 2013/36/EU of the European Parliament and of the Council of 26 June 2013 on access to the activity of credit institutions and the prudential supervision of credit institutions and investment firms, amending Directive 2002/87/EC and repealing Directives 2006/48/EC and 2006/49/EC, http://eur-lex.europa.eu/legal-content/EN/TXT/?uri=CELEX:32013L0036, [22.05.2018.]
} 
cycles. The effectiveness of macroprudential policy depends mostly on interaction with other policies that also have a focus on systemic risk. In order to achieve the full impact of macroprudential tools it is essential to define objectives, prepare adequate institutional foundations and make accurate calibration of macroprudential tools. Although, there are several costs that could appear in transmission process; adjustment costs (that appears in phase-in and step-wise tightening), efficiency costs (the costs that affect lenders in order to act discouraging on their behaviour) and output costs (some macroprudential constraint can have adverse impact on output growth in short-run). In addition, the problem for macroprudential policy could be the potential leakages, like a migration of financial activity outside the supervision of macroprudential regulator [22]. Several researches showed that unconventional monetary policy is more effective in expansions than in recessions, which particularly refers to restart of business investment cycle [35]. In the turns when economy needs the stimulus for recovery and shift toward upturns in credit and business cycle, extra measures and instruments referring to strengthening banking capital base and extra reservations for new credit granting's, discourage banks for credit activity toward the real sector and push them toward public and state sector. In that situation, the real economy is losing the capital for recovery the production and stays longer in downturn of business cycle which results in imposing extra efficiency and output costs for economy as a whole.

Although, prudential regulation increases the long-term financial stability, the shortterm costs of building up capital and liquidity buffers are even higher [17]. Pasricha et al [30] were analysing the influence of changes in capital controls and currency-based prudential measures in 17 major emerging market economies (EMEs) over the period 20012011. They concluded that implementation of capital controls do not help countries in avoiding the trade-offs of the monetary policy trilemma. In addition, they found that the usefulness of these measures weakened in the post-crisis environment. Devereux et al. [12] studied the benefits of capital controls in small open economy and they confirmed that the macroprudential capital controls in a crisis may be welfare reducing.

\section{Methodology and data}

The research was conducted for the period of 2000 - 2019, based on the data of the Croatian National Bank and the Croatian Bureau of Statistics using logarithmic quarterly data. The analysis is made by using Granger Causality Test and ADRL Bounds Test. The data used in analysis were: a) Reserve requirement; ARRR, b) Countercyclical capital buffer; APLC_dummy, c) Minimum required foreign currency claims; MFEL, d) Credit activity toward real sector; NFDS_log_d, e) Gross domestic product; GDP.

The cointegration analysis between the variables requires a test for the existence of a unit root for each individual time series. In order to determine the level of integration of the variables above, first was applied the Augmented Dickey-Fuller test (ADF test). (Dickey, Fuller, 1981).

The results of ADF test are listed below (Tab. 1):

Table 1 Augmented Dickey- Fuller test

\begin{tabular}{ccccc}
\hline Variable & $\begin{array}{c}\text { Lag } \\
\text { Lengt } \\
\boldsymbol{h}\end{array}$ & $\begin{array}{c}\text { t-statistic } \\
\boldsymbol{A D P F}\end{array}$ & $\boldsymbol{p}$ & Test for unit root: \\
\hline NFDS_LOG_D & $\begin{array}{c}(\mathrm{SIC}) \\
1\end{array}$ & -4.310317 & 0.0009 & In level with intercept \\
\hline APLC_dummy & $\begin{array}{c}\mathrm{AIC}) \\
0\end{array}$ & -8.774964 & 0.0000 & In 1 $^{\text {st }}$ difference with intercept \\
\hline
\end{tabular}




\begin{tabular}{ccccc}
\hline ARRR_LOG & $(\mathrm{AIC})$ & -3.585962 & 0.0082 & In level with intercept \\
& 0 & & & \\
\hline GDP_LOG & $(\mathrm{AIC})$ & -32.57598 & 0.0001 & In $2^{\text {nd }}$ difference with intercept \\
\hline MFEL_LOG & $\begin{array}{c}\text { (AIC) } \\
0\end{array}$ & -8.332366 & 0.0000 & In $1^{\text {st }}$ difference with intercept \\
\hline \multicolumn{5}{c}{ Source: Authors calculation }
\end{tabular}

According to the unit root test, variables credit activity toward the real sector and reserve requirement are stationary in the level. Countercyclical capital buffer and Minimum required foreign currency claims are stationary in their first differences. Variable GDP is stationary in the second difference. The conclusions drawn from some analysis could be mistaken if the choice of lag lengths is not appropriately chosen. The lag lengths critically affect the results of the analysis [36].

The lag lengths for chosen variables are listed in the table below (Tab. 2)

Table 2 The lag lengths of dependent variables

\begin{tabular}{|l|c|c|}
\hline \multirow{2}{*}{$\begin{array}{c}\text { Dependent Variable } \\
\text { NFDS_LOG_D }\end{array}$} & \multicolumn{2}{|c|}{ Vector Autoregression Estimates } \\
\cline { 2 - 3 } & t-statistics & lag \\
\hline APLC_dummy & -1.43743 & 1 \\
\hline ARRR_LOG & -2.01036 & 3 \\
\hline GDP_LOG & -2.93412 & 6 \\
\hline MFEL_LOG & -2.20454 & 5 \\
\hline
\end{tabular}

Source: Authors`calculation

Granger test examines whether one variable is statistically significant and offers the information about the other variables, with the existence of time delay [18]. In this analysis, Granger test should be expanded with error correction model, due to the results of cointegration analysis.

Table 3 Granger Causality Tests

\begin{tabular}{|l|c|}
\hline Variable & \multicolumn{1}{c|}{ Prob. } \\
MFEL_LOG does not Granger Cause NFDS_LOG_D & 0,9606 \\
\hline GDP_LOG does not Granger Cause NFDS_LOG_D & 0,0934 \\
\hline APLC_DUMMY does not Granger Cause NFDS_LOG_D & 0,9593 \\
\hline ARRR_LOG does not Granger Cause NFDS_LOG_D & 0,6384 \\
\hline \multicolumn{2}{|c}{ Source: Authors`calculation }
\end{tabular}

The results of Granger test (Tab. 3) showed that reserve requirement, countercyclical capital buffer and minimum required foreign currency claims cause banks' credit activity toward non-financial (real) sector.

Given that the variables are non-stationary at the same levels, ARDL test was performed. 
Table 4 ARDL Bounds Test

$$
\text { Null Hypothesis: No long-run relationships exist }
$$

\begin{tabular}{lll}
\hline Test Statistic & Value & $\mathrm{k}$ \\
\hline F-statistic & $\mathbf{4 , 5 6 6 2 3 6}$ & 4 \\
\hline Critical Value Bounds & & \\
\hline Significance & I0 Bound & I1 Bound \\
\hline $10 \%$ & 2,45 & 3,52 \\
\hline $5 \%$ & 2,86 & 4,01 \\
\hline $2,5 \%$ & 3,25 & 4,49 \\
\hline $1 \%$ & 3,74 & 4,50 \\
\hline & Source: Authors`calculation
\end{tabular}

Since F-statistic is 4,566 and it is greater than critical value for the upper bound of I (1), we conclude that there exist cointegration between variables (Tab. 4). The ARDL Bounds test confirmed that there is long-run relationship. The research confirmed the thesis that in the period of downturn, countercyclical tools, especially the ones that refers to credit activity, bring to leakages, which makes the macroprudential instruments less effective. The similar results were obtained by Tressel and Zhang [37]. They found that macroprudential instruments that affect cost of bank capital are effective in decreasing mortgage credit growth. Restrictive macroprudential policy increases the cost of borrowing on financial markets and interest rates on banks' deposits, which increases the interest rates on credits. The higher price of sources of funding decreases credit demand, and finally reduces the economic activity. The results of the analysis show that countercyclical macroprudential policy contributes to financial stability in whole in order to decrease expansive credit activity. The same results were obtained by Rubio and Unsal [32] in analysis of effectiveness of macroprudential policy in developing countries. Their research showed that macroprudential policy is effective in reducing financial instability. The similar findings for macroprudential effectiveness are discussed by Turner [38], especially for small open economies. Macroprudential tools that aim at credit activity in domestic and foreign currency borrowing proved to be the best solution for small open countries that face risky credit expansion. Although macroprudential instrument contribute to financial stability, there are some costs of countercyclical macroprudential policy. The most important issue of introducing the macroprudential instruments, is that countercyclical instruments are weakening economy if no financial crisis occurs. Furthermore, if the crisis occurs, and the economy is weak, the future recovery will be even harder, and the duration of crisis will be longer [34].

\section{Conclusion}

Macroprudential instruments contribute to the overall financial stability and are specially focused on stability of the banking sector. The analysis made in this paper confirmed the thesis that in the period of downturn, the macroprudential instruments decrease the bank' credit activity which has negative impact to the real sector. The negative impact means that the countercyclical capital buffers and regulatory requirements decreases the banks' credit activity toward the real sector which extends the recovery period in post-crisis period. In this paper, Granger test confirmed that reserve requirement, countercyclical capital buffer and minimum foreign currency claims cause the banks' credit activity toward real sector. Also, the ARDL Bounds Test confirmed that there exist long-run cointegration between variables. 
The research presented in this paper showed that the policy makers should consider the overall advantages and disadvantages of general policies and their impact to the economy in total. In order to avoid leakages, the macroprudential instruments should be considered in interaction with fiscal policy and other public policies by creating positive externalities for subject that are addressed by a range of countercyclical tools. The results of the research bring evidence on the effects of using unconventional monetary policy instruments and macroprudential policy instruments. We provide a new point of estimation macroprudential instruments (aimed at decreasing of upturns in period credit cycles expansion) and question their validity in post-crisis period, offering the new avenues for futures research and analysis.

\section{References}

1. Altavilla, C., Boucinha, M., \& Peydró, J. L. (2018). Monetary policy and bank profitability in a low interest rate environment. Economic Policy, 33(96), 531-586.

2. Altunbas, Y., Binici, M., \& Gambacorta, L. (2018). Macroprudential policy and bank risk. Journal of International Money and Finance, 81, 203-220.

3. Bank of England (2015). EU prudential rules for banks, building societies and investment firms - Capital Requirements Directive IV (CRD IV), Retrieved from: http://www.bankofengland.co.uk/Pages/home.aspx,

4. Basten, C., \& Koch, C. (2015). Higher bank capital requirements and mortgage pricing: evidence from the Countercyclical Capital Buffer (CCB).

5. Benigno, G., Chen, H., Otrok, C., Rebucci, A., \& Young, E. R. (2016). Optimal capital controls and real exchange rate policies: A pecuniary externality perspective. Journal of monetary economics, 84, 147-165.

6. Budnik, K. B., \& Bochmann, P. (2017). Capital and liquidity buffers and the resilience of the banking system in the euro area.

7. Budnik, K. B., \& Kleibl, J. (2018). Macroprudential regulation in the European Union in 1995-2014: introducing a new data set on policy actions of a macroprudential nature.

8. Chen, M. J., \& Columba, M. F. (2016). Macroprudential and monetary policy interactions in a DSGE model for Sweden. International Monetary Fund.

9. Collard, F., Dellas, H., Diba, B., \& Loisel, O. (2017). Optimal monetary and prudential policies. American Economic Journal: Macroeconomics, 9(1), 40-87.

10. Bruyckere, V. D. (2015). Systemic risk rankings and network centrality in the European banking sector.

11. Demirgüç-Kunt, A., Detragiache, E., Tressel, T. (2006). Banking on the principles: Compliance with Basel Core Principles and bank soundness, Journal of Financial Intermediation, 17(4), $511-542$.

12. Devereux, M. B., Young, E. R., \& Yu, C. (2019). Capital controls and monetary policy in sudden-stop economies. Journal of Monetary Economics, 103, 52-74.

13. Dickey, D. A., \& Fuller, W. A. (1981). Likelihood ratio statistics for autoregressive time series with a unit root. Econometrica: journal of the Econometric Society, 49(4), 1057-1072.

14. Directive 2013/36/EU of the European Parliament and of the Council. (2013). Official Journal of the European union, pp. 338-436, Retrieved from: http://eurlex.europa.eu/LexUriServ/LexUriServ.do?uri=OJ:L:2013:176:0338:0436:En:PDF. 
15. European central bank, (2012). Financial stability review, June 2012, Retrieved from: https://www.ecb.europa.eu/pub/pdf/other/financialstabilityreview201206en.pdf?6b3b7 eb08f53f6ad069f5b6dd15275c8.

16. Fratzscher, M., Gloede, O., Menkhoff, L., Sarno, L., \& Stöhr, T. (2019). When is foreign exchange intervention effective? Evidence from 33 countries. American Economic Journal: Macroeconomics, 11(1), 132-56.

17. Galiay, A., \& Maurin, L. (2015). Drivers of banks' cost of debt and long-term benefits of regulation-an empirical analysis based on EU banks.

18. Granger, C. W. (1969). Investigating causal relations by econometric models and cross-spectral methods. Econometrica: journal of the Econometric Society, 37(3), 424438.

19. Hartmann, P. (2015). Real estate markets and macroprudential policy in Europe. Journal of Money, Credit and Banking, 47(S1), 69-80.

20. Hattori, M., Schrimpf, A., \& Sushko, V. (2016). The response of tail risk perceptions to unconventional monetary policy. American Economic Journal: Macroeconomics, 8(2), 111-36.

21. IMF Country Report No. 18/164 (2018) Technical note - Macroprudential Policy Framework and Tools, http://www.imf.org/en/publications/cr/issues/2018/06/08 /romania-financial-sector-assessment-program-technical-note-macroprudential-policyframework-45967.

22. IMF-FSB-BIS (2016). Elements of Effective Macroprudential Policies, http://www.imf.org/external/np/g20/pdf/2016/083116.pdf,

23. Jacome, L. I., \& Nier, E. W. (2011). Macroprudential policy: Protecting the whole. Finance \& Development. Retrieved from http://www. imf. org/external/pubs/ft/fandd/basics/macropru. htm.

24. Kenç, T. (2016). Macroprudential regulation: history, theory and policy. BIS Paper, (86c).

25. Levine, P., Lima, D. (2015). Policy mandates for macro-prudential and monetary policies in a new Keynesian framework, Working Paper Series No 1784, https://www.ecb.europa.eu/pub/pdf/scpwps/ecbwp1784.en.pdf?93eba4bb02e9f7aac335 60293a6bb3dc, [23.08.2018.]

26. Lim, C., Columba, F., Costa, A., Kongamut, P., Otani, A., Saiyid, M., Wezel, T., Wu, X. (2011). Macroprudential Policy: What Instruments and How to Use Them?, IMF Working Paper, Retrieved from: https://www.imf.org/external/pubs/ft/wp/2011/wp11 238.pdf,

27. Lozej, M., Onorante, L., Rannenberg, A. (2018). Countercyclical capital regulation in a small open economy DSGE model, Working paper Series No 2144, https://ideas.repec.org/p/cbi/wpaper/03-rt-17.html.

28. Magilla, M., Quinzii, M., Rochet, J.C. (2019) The safe asset, banking equilibrium, and optimal central bank monetary, prudential and balance-sheet policies, Retrieved from: https://www.sciencedirect.com/science/article/abs/pii/S0304393219300418.

29. Moder, I. (2017). Spillovers from the ECB's non-standard monetary policy measures on south-eastern Europe, Working Paper Series No 2095, https://www.ecb.europa.eu/pub/pdf/scpwps/ecb.wp2095.en.pdf?d2291e689d800daa269 debd14f15a9ec.

30. Pasricha, G., Falagiarda, M., Bijsterbosch, M., Aizenman, J. (2015). Domestic and multilateral effects of capital controls in emerging markets, Working Paper Series No 
1844, https://www.ecb.europa.eu/pub/pdf/scpwps/ecbwp1844.en.pdf?3b3298ee7067d2 84886cb7180a7bafe9.

31. Peltonen, T., Rancan, M., Sarlin, P. (2015). Interconnectedness of the banking sector as a vulnerability to crises, Working paper Series No. 1866, https://www.ecb.europa .eu/pub/pdf/scpwps/ecbwp1866.en.pdf.

32. Rubio, M., Filiz Unsal, D. (2017). Macroprudential Policy, Incomplete Information and Inequality: The case of Low-Income and Developing Countries, IMF Working Paper No. 1759, https://www.imf.org/en/Publications/WP/Issues/2017/03/21/Macro prudential-Policy-Incomplete-Information-and-Inequality-The-case-of-Low-Income-an d-44752.

33. Schuler, Yves S., Hiebert, P.P., Peltonen, T.A. (2015). Characterising the financial cycle: a multivariate and time-varying approach, Working Paper Series No 1846, https://www.ecb.europa.eu/pub/pdf/scpwps/ecbwp1846.en.pdf.

34. Svensson, L. E. (2017). Cost-benefit analysis of leaning against the wind. Journal of Monetary Economics, 90, 193-213.

35. Tenreyro, S., \& Thwaites, G. (2016). Pushing on a string: US monetary policy is less powerful in recessions. American Economic Journal: Macroeconomics, 8(4), 43-74.

36. Toda, H. Y., \& Phillips, P. C. (1994). Vector autoregression and causality: a theoretical overview and simulation study. Econometric reviews, 13(2), 259-285.

37. Tressel, T., \& Zhang, Y. (2016). Effectiveness and channels of macroprudential instruments: Lessons from the Euro Area.

38. Turner, P. (2016). Macroprudential policies, the long-term interest rate and the exchange rate.

39. Upper, C. (2017). Macroprudential frameworks, implementation and relationship with other policies-overview. BIS Paper, (94).

40. Van der Ghote, A. (2018). Coordinating monetary and financial regulatory policies. Working Paper Series No 2155, http://www.lse.ac.uk/economics/Assets/Doc uments/seminars/mcrw-seminar-papers/Coordinating-Monetary-and-FinancialRegulatory-Policies.pdf.

41. Williamson, S. D. (2018). Low real interest rates, collateral misrepresentation, and monetary policy. American Economic Journal: Macroeconomics, 10(4), 202-33. 